\title{
Editorial
}

\section{Special issue on the role of translation and transcription in learning and memory}

The editors of Learning \& Memory are pleased to bring you this special issue covering the role of translation and transcription in learning and memory. For decades it has been accepted that long-term memory requires protein synthesis, and that synaptic plasticity supports learning and memory. In addition, data have accumulated indicating that translation of mRNA at the synapse plays a major role in synaptic plasticity, and more recently, increasing evidence suggests that disregulation of transcription/ translation pathways contributes to psychiatric and substance abuse disorders, and other disorders affecting learning and memory. This special issue brings together eight research and review articles from leaders in the field and covers this topic from be- havioral to molecular approaches. We believe this issue represents an important contribution to the field, and it will be featured at the annual meeting of the Pavlovian Society in Vancouver, BC, the 18th Annual Meeting of the Molecular and Cellular Cognition Society, and the 2019 Meeting of the Society for Neuroscience.
Susan Cushman, PhD Assistant Editor

John H. Byrne, PhD Editor 


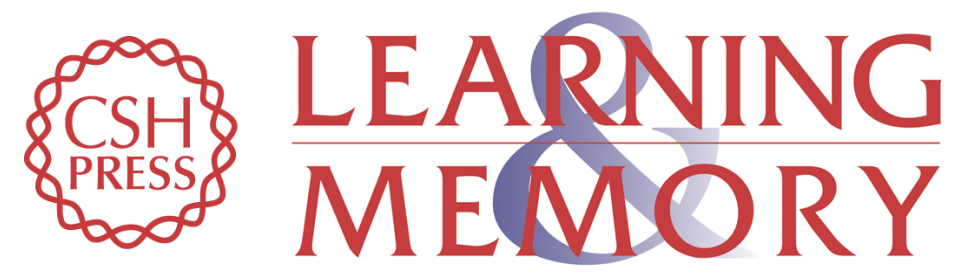

\section{Special issue on the role of translation and transcription in learning and memory}

Susan Cushman and John H. Byrne

Learn. Mem. 2019, 26:

Access the most recent version at doi:10.1101/Im.050302.119

$\begin{aligned} & \begin{array}{r}\text { Creative } \\ \text { Commons } \\ \text { License }\end{array} \begin{array}{l}\text { This article is distributed exclusively by Cold Spring Harbor Laboratory Press for the } \\ \text { first } 12 \text { months after the full-issue publication date (see } \\ \text { http://learnmem.cshlp.org/site/misc/terms.xhtml). After } 12 \text { months, it is available under } \\ \text { a Creative Commons License (Attribution-NonCommercial } 4.0 \text { International), as } \\ \text { described at http://creativecommons.org/licenses/by-nc/4.0/. }\end{array} \\ & \begin{array}{l}\text { Receive free email alerts when new articles cite this article - sign up in the box at the } \\ \text { top right corner of the article or click here. }\end{array} \\ & \begin{array}{c}\text { Service } \\ \text { Serting }\end{array}\end{aligned}$

